\title{
AL-A'RAF
}

Jurnal Pemikiran Islam dan Filsafat

SURAKARTA http://ejournal.iainsurakarta.ac.id/index.php/al-araf

ISSN: 1693-9867 (p); 2527-5119 (e)

DOI: $10.22515 /$ ajpif.v14i2.848

\section{MAKNA SEKSUALITAS DALAM ALQUR'AN MENURUT HUSEIN MUHAMMAD}

\author{
Muhammad Tobroni \\ UIN Sunan Kalijaga, Yogyakarta
}

\begin{tabular}{l}
\hline \\
\hline Keywords: \\
Tafsir of \\
sexuality, Husein \\
Muhammad, \\
and Sociology of \\
knowledge \\
\hline
\end{tabular}

\begin{abstract}
Abstrak
Perkembangan sebuah penafsiran adalah sebuah keniscayaan. Penafsiran merupakan proses dalam rangka merespon realitas sosial, sekaligus memberikan solusi bagi problematika kehidupan masyarakat. Penafsiran terhadap ayat-ayat seksualitas misalnya, memiliki berbagai makna untuk ditafsirkan kembali. Tafsir yang dilakukan oleh para ulama' klasik masih menyisakan persoalan, khususnya pada penafsiran ayat-ayat bernuansa feminis. Artikel ini bertujuan untuk mengelaborasi pemikiran Husein Muhammad terhadap makna seksualitas dalam ayat-ayat yang bernuansa feminis. Alat analisis yang digunakan untuk melihatnya adalah sosiologi pengetahuan Karl Manheim, agar dapat memahami konteks pemikiran dari Husein sebagai penjelas ayat-ayat bernuansa feminis. Hasil kajian menunjukkan bahwa Islam yang ada saat ini merupakan hasil pergumulan agama dan budaya. Sehingga Q.S. Alrum 30: 2I, harus dilihat sebagai: pertama, sebagai cara manusia menyalurkan hasrat libidonya untuk memperoleh kepuasan seksual. Kedua, ikhtiar manusia untuk melestarikan kehidupan di bumi. Pernikahan mengandung fungsi prokreasi dan reproduksi. Ketiga, menjadi wahana manusia menemukan tempat ketenangan dan keindahan.
\end{abstract}

Abstract
The development of interpretation is an inevitability. Interpretation
is a process to respond social reality, at once giving the solution for
the societal problematic life. For instance, the interpretations of
sexuality verses were having the various meaning which is able to be re-
interpreted. The interpretation conducted by the classical ulama' was
still leaving some problems, especially on the verses about feminism.
This article aims to elaborate the Husein Muhammad thought on
the meaning of sexuality in the feminism verses. The analysis tools 
used is the sociological knowledge of Karl Manheim, in order to be able to understand the context of Husein Muhammad thought as an explanation of the feminism verses. The result of the study showed that Islam is a product of the struggle between religion and culture. So that, Q.S. Alrum 30: 21 must be seen as firstly, as a human way to channeling the libido passion to get sexual satisfaction. Secondly, the human effort is to preserving life on earth, so that marriage is having a function to pro-create and reproduction. Thirdly, as a human way to find out the peace and beautiful place to live in

\section{Pendahuluan}

Alqur'an sebagai sumber utama ajaran Islam mengundang banyak pemikir untuk mengelaborasi kandungan makna di dalamnya. Alqur'an terus dipahami dan digali kandungan maknanya sesuai dengan konteks zaman. Sejarah penafsiran Alqur'an sendiri telah mengalami perkembangan sejak masa Nabi hingga saat ini. Pada masa hidup Nabi, umat muslim bisa langsung bertanya ketika ada ayat Alqur'an yang tidak dapat dipahami. Nabi pun secara langsung dapat menjelaskan maksud dari kandungan sebuah ayat. Itulah sebabnya Nabi juga disebut sebagai mufassir alawwal. Nabi tidak hanya bertindak sebagai penyampai wahyu, tapi juga penjelas dari ayat-ayat Alqur'an. ${ }^{1}$

Sepeninggal Nabi, para sahabat mengalami kesulitan untuk mencari rujukan dan bertanya maksud dari lafadz. Alqur'an yang belum dipahami tafsirannya. Selain itu, seiring perkembangan zaman, karena problematika umat terus mengalami perkembangan, maka model tafsir pun terus berlanjut. Salah satu problematika yang penting untuk dikaji adalah mencermati ulang penafsiran ayat-ayat tentang seksualitas. Hal ini didasarkan pada penafsiran ulama' klasik seperti Althabari dan Ibn Katsir, ${ }^{2}$ yang masih memanfaatkan sumber riwayat (ma'tsur) dan menyisakan problem berupa superioritas laki-laki atas perempuan.

1 Said Agil Husein Almunawar, Alqur'an Membangun Tradisi Kesalehan Hakiki (Ciputat: Ciputat Press, 2005), 64-65.

2 Adapun penfasir klasik selain kedua tokoh di atas adalah: Abu Abdullah Muhammad Alqurthubi, Fakhr Aldin Alrazi, Abu Bakar Muhammad Ibnu Alarabi, Alzamakhsyari. Lihat. Husein Muhammad, Islam Agama Ramah Perempuan Pembelaan Kiai Pesantren (Yogyakarta: LKiS, 2001), 81. 
Dengan demikian, sebuah keniscayaan bagi mufassir untuk menawarkan paradigma baru dalam memproduksi makna Alqur'an dengan nuansa feminis, mengingat adanya pluralitas makna ayat Alqur'an. Pandangan tersebut berangkat dari asumsi dasar bahwa Alqur'an telah mendudukkan laki-laki dan perempuan setara di hadapan Allah. Yang membedakannya hanyalah ketakwaan. Penafsiran yang berkembang dalam tradisi Islam, kebanyakan cendrung bersifat patriarki. Dalam pandangan Zaitunah penyebab munculnya tafsir diskriminatif model patriarkal ini disebabkan dominannya para penafsir laki-laki. Kegiatan perempuan yang banyak dibatasi dengan tafsir agama menjadikan dominasi perempuan tidak sebanding dengan laki-laki. ${ }^{3}$

Dari beberapa penafsiran yang ada, permasalahan ini terletak pada dasar pemahaman yang memposisikan antara laki-laki dan perempuan. Umumnya para mufasir berpandangan bahwa perempuan itu makhluk yang lemah dibanding laki-laki. Keputusan ini dihubungkan dengan pernyataan Alqur'an dalam surat Alnisa' yang artinya;

"Kaum laki-laki itu adalah pemimpin bagi kaum wanita, oleh karena Allah telah melebihkan sebahagian mereka (laki-laki) atas sebahagian yang lain (wanita), dan karena mereka (laki-laki) telah menafkahkan sebagian dari harta mereka. (Q.S. Alnisa')."

Beberapa mufassir mempunyai pandangan yang sama terkait ayat tersebut. Sebagaimana penafsiran Alzamakhsyari yang menyatakan bahwa laki-laki memang lebih unggul daripada perempuan. Keunggulan tersebut bisa dilihat dari beberapa aspek antara lain, akal, ketegasan, semangat, keperkasaan, dan keberanian. ${ }^{4} \mathrm{Hal}$ serupa juga dikemukakan oleh beberapa

3 Zaitunah Subhan, Tafsir Kebencian: Studi Bias Gender dalam Tafsir Qur'an (Yogyakarta: LKiS, 1999).

4 Alzamakhsyari, Alkasyaf 'an Haqaiq Alghawamid Altanzil (Beirut: Dar Alkitab Alarabi, n.d.), 505. 
mufassir lain, seperti Fakhruddin Alrazi, ${ }^{5}$ Althabari, ${ }^{6}$ dan Ibn Katsir. ${ }^{7}$ Ayat tersebut, oleh para mufasir disimpulkan dengan berbagai kelebihan yang dimiliki oleh laki-laki dibandingkan perempuan. Para mufasir beranggapan bahwa kemampuan yang dimiliki oleh laki-laki atas perempuan adalah pemberian dari Tuhan.

Husein Muhammad memberikan pemahaman berbeda dari pandangan para mufasir di atas. Menurutnya, kekuasaan dan kekuatan laki-laki yang memperoleh dasar legitimasi agama, secara tidak disadari menimbulkan perlakuan yang tidak adil terhadap kaum perempuan, ternyata semata-mata karena jenis kelamin sang perempuan. Pada gilirannya hal ini berdampak negatif bagi langkah perempuan di tengah kehidupan bermasyarakat. $^{8}$

Husein Muhammad memberikan penafsiran yang berbeda dari lainnya. Selain karena rujukan keilmuan Husein Muhammad bersumber dari kitab-kitab klasik, konteks pemahamannya terhadap seksualitas dapat dikategorikan sebagai pembaharu dalam pemikiran feminisme. Oleh karena itu, artikel ini membahas makna seksualitas dalam penafsiran Husein Muhammad, yang didasarkan pada karya-karyanya. Dengan analisis sosiologi pengetahuan Karl Manheim, artikel ini hendak mengetahui makna seksualitas dalam penafsiran Husein Muhammad sehingga tidak ada lagi pandangan negatif, seperti labeling liberal dan lain sebagainya. Sosiologi pengetahuan diposisikan untuk melihat pemikiran Husein Muhammad secara menyeluruh, sehingga dapat memahami konteks pemikirannya, sebagai penjelas ayat-ayat bernuansa feminis.

5 Fakhrudin Alrazi, Tafsir Almafatih Alghaib (Beirut: Dar Alihya Alturos Alarabi, n.d.), 70 .

6 Althabari, Jami' Albayan 'an Ta'wili Alqur'an (Alqahirah: Dar Hijr, 2001), 687.

7 Ibn Katsir, Tafsir Alqur'an Aladzim (Yaman: Dar Althabi'ah, 1999), 292.

8 Husein Muhammad, Islam Agama Ramah Perempuan Pembelaan Kiai Pesantren. 


\section{Sekilas tentang Husein Muhammad}

Husein Muhammad lahir pada tanggal 9 Mei 1953 di Arjawinangun, Cirebon, Jawa Barat. Husein Muhammad merupakan bagian dari keluarga besar pondok Darut Tauhid Arjawinangun. Ayah Husein Muhammad bernama Asyrofuddin, yang merupakan keluarga sederhana dengan latar belakang pesantren. Sedangkan ibu Husein Muhammad adalah Ummu Salma Syathori, putri dari K.H. Syathori (keturunan pendiri pondok Darut Tauhid). ${ }^{9}$ Husein menikah dengan Lilik Nihayah Fuad Amin, dan dikaruniai lima orang putra-putri, yaitu: Hilya Auliya, Layali Hilpada, Muhammad Fayyaz Mumtaz, Najlah Hammada, dan Fazla Muhammad. ${ }^{10}$

Masa Kecil Husein Muhammad menempuh pendidikan dasar dan diniyah-nya di lingkungan pondok pesantren Darut Tauhid Arjawinangun, yang selesai pada tahun 1966. Setelah tamat dari pendidikan dasar, Husein melanjutkan pendidikannya di SMPN 1 dan selesai pada tahun 1969 di desa Arjawinangun. ${ }^{11}$ Semasa Husein Muhammad belajar di Sekolah Menengah (SMP) banyak kegiatan dan seminar yang diikutinya. Dengan masuknya Husein ke sekolah umum, mencerminkan bahwa keluarga pondok pesantren Darut Tauhid tidak eksklusif dalam memandang Agama. Hal ini tidak lepas dari pendiri pondok pesantren K.H. Syathori yang memandang perlunya sikap moderat terhadap pembelajaran pada masa modern. Salah satu contoh bahwa K.H. Syathrori menggunakan perlengkapan sekolah berbasis modern bisa dilihat dari keberadaan bangku, papan tulis dan kelas dalam lingkungan pesantren. ${ }^{12}$

Setelah menamatkan pendidikan di SMP, Husein melanjutkan pendidikannya di pondok pesantren Lirboyo, Kediri, Jawa Timur. Husein

9 Nuruzzaman, Kiai Husein Membela Perempuan (Yogyakarta: Pustaka Pesantren, 2005), 110.

10 Susanti, "Husein Muhammad Antara Feminis Islam Dan Feminis Liberal," Teosofi Volume 4, no. 1 (2014): 119.

11 Husein Muhammad, dkk, Figh Seksualitas Risalah Islam untuk Pemenuban HakHak Seksualitas (Jakarta: Pkbi, 2011), 129.

12 Nuruzzaman, Kiai Husein Membela Perempuan,110. 
menyelesaikan pendidikannya di Lirboyo selama tiga tahun, kemudian melanjutkan pendidikannya di Perguruan Tinggi Ilmu Alqur'an (PTIQ) Jakarta. Di PTIQ semua mahasiswa diwajibkan untuk menghafal Alqur'an. Fokus kajiannya pun dikhususkan untuk mengkaji dan berbasis Alqur'an. ${ }^{13}$

Husein Muhammad menghabiskan waktu lima tahun untuk menempuh jenjang S1 di PTIQ. Semasa di PTIQ, Husein banyak mengikuti kegiatan, baik ektra maupun intra kampus. Husein bersama temantemannya memelopori adanya majalah dinding dalam bentuk reportase di kampus. Husein pun pernah mengikuti pendidikan jurnalistik dengan Mustafa Hilmy yang pada saat itu menjadi redaktur Tempo. Dengan pelatihan yang serius dan minat yang tinggi, Husein memiliki kemapuan dalam bidang jurnalistik. Keaktifan Husein mengikuti kegiatan di kampus, membawanya menjadi Ketua 1 Dewan Mahasiswa, and menjadi Ketua Umum Dewan Mahasiswa pada tahun 1979. ${ }^{14}$

Pada tahun 1979, setelah Husein menyelesaikan pendidikannya di PTIQ kemudian berangkat ke Mesir untuk melanjutkan studinya di Universitas Alazhar, sekaligus menuruti saran dari gurunya yang bernama Ibrahim Husein, untuk mempelajari ilmu tafsir Alqur'an. Menurut gurunya, Mesir lebih tepat dijadikan tempat belajar tafsir, karena Mesir dianggap lebih terbuka dalam bidang ilmu pengetahuan, dibanding negara-negara lain di Timur Tengah.

Pada tahun 1983, Husein menyelesaikan studinya di Universitas Alazhar dan kembali ke Indonesia, dan menjadi penerus misi kakeknya di Darut Tauhid, Arjawinangun. ${ }^{15}$ Saat itu, Husein sempat ditawari untuk menjadi pengajar di PTIQ Jakarta, namun ditolaknya dengan alasan pondok pesantren kakeknya sangat membutuhkan pengembangan.

13 Nuruzzaman, Kiai Husein Membela Perempuan,,112.

14 Nuruzzaman, Kiai Husein Membela Perempuan, 113.

15 Samsul Zakaria, "Kepemimpinan Perempuan dalam Persepektif Hukum Islam (Studi Komparatif antara Pemikiran K.H. Husein Muhammad dan Prof. Siti Musdah Mulia)," Khasanah Vol. 6, no. 1 (2013): 78. 


\section{Menelisik Makna Seksualitas}

Persoalan seksualitas seringkali menjadi perbincangan sekaligus objek kajian di berbagai bidang keilmuan. Persoalan terkait dengan pengertian seksualitas sendiri tidaklah sederhana, sehingga masih menjadi perdebatan. Dalam kamus besar bahasa Indonesia (KBBI), seksualitas diartikan sebagai: (1) ciri, sifat, atau peranan seks, (2) dorongan seks dan (3) kehidupan seks. Menurut Husein Muhammad seksualitas adalah sebuah proses sosial-budaya yang mengarahkan hasrat atau birahi manusia. Seksualitas dipengaruhi oleh interaksi faktor-faktor biologis, psikologis, sosial, ekonomi, politik, agama, dan spiritualitas. Seksualitas merupakan hal positif, berhubungan dengan jati diri dan kejujuran seseorang terhadap dirinya. Sayangnya, masyarakat umumnya masih melihat seksualitas sebagai negatif, bahkan tabu untuk dibicarakan. ${ }^{16}$

Michael Foucault, dalam konteks ini menegaskan bahwa seksualitas merupakan hasil konstruksi sosial. Seksualitas sangat erat hubungannya dengan kekuasaan. Seksualitas menurutnya adalah produk historis atau sistem pengawasan, kontrol, dan ekspresi dari yang membangun suasana sosial. Segala unsur represi, yakni pelarangan, penolakan, penyensoran dan penyangkalan, merupakan mesin sentral dalam konstruksi sosial, termasuk konkstruksi seksualitas. ${ }^{17}$

Secara lebih terperinci, Foucault menjelaskan bagaimana kekuasaan mengkonstruksi seksualitas, melalui tahapan berikut: pertama, hubungan negatif. Di antara kekuasaan dan seks, representasi hanya terjadi dalam bentuk negatif: penyingkiran, pengabaian, penolakan, penghambatan dan lain-lain. Kedua, instansi aturan. Kekuasaan hanyalah apa yang menentukan hukum seks. Seks ternyata ditempatkan oleh kekuasaan di

${ }^{16}$ Husein Muhammad, dkk., Figh Seksualitas Risalah Islam untuk Pemenuhan HakHak Seksualitas, 11.

${ }^{17}$ Nenden Lilis A, "Faktor-Faktor yang Mempengaruhi Maraknya Karya Sastra yang Mengupas Persialan Seksualitas dan Tubuh dalam Kesusastraan Indonesia Modern pada Era Reformasi," Yin Yang Vol.4, no. 1 (2009). 
bawah sistem biner: halal-haram, boleh-terlarang. Ketiga, Siklus larangan: kamu tidak boleh dekat-dekat, kamu tidak boleh menyentuh, kamu tidak boleh merasa nikmat, kamu tidak boleh bicara, kamu tidak boleh muncul. Kekuasaan hanya memfungsikan hukum larangan, agar seks menyangkal dirinya sendiri. Keempat, logika sensor. Larangan ini memiliki tiga bentuk; menegaskan bahwa "itu" tidak boleh, menghalangi "itu" untuk dikatakan, menyangkal bahwa "itu” ada. Kelima, kesatuan perangkat. Kekuasan atas seks, diterapkan secara merata di segala tataran, dari atas ke bawah, dalam keputusan global ataupun intervensi yang bersifat sangat halus. ${ }^{18}$

Dengandemikian, persoalan seksualitas terjadiatas dasarketidakadilan antara laki-laki dan perempuan. Sehingga, persoalan yang perlu dicermati terkait ketidakadilan dan kekerasan seksual yang dialami kaum perempuan adalah: pertama, tradisi Islam dalam fiqh yang menempatkan perempuan sebagai pelayan kebutuhan seksual pria dan pembangkit birahi seksual. Kedua, kecenderungan konsumerisme tubuh perempuan dalam peradaban industri modern. Ketiga, tradisi lokal, khususnya Jawa, yang menempatkan perempuan sebagai kemuliaan laki-laki. ${ }^{19}$

Konstruksi seksualitas perempuan sebagaimana dijelaskan di atas, dibangun di atas legitimasi agama merupakan sebuah ironi. Berbagai ayat dan hadith yang secara literal mensubordinasi perempuan dan seksualitasnya dijadikan sebagai argumen untuk membenarkan praktek seksual tersebut. Beberapa ayat Alqur'an yang menyebutkan superioritas laki-laki atas perempuan, digunakan untuk menekan seksualitas perempuan dan menempatkannya sebagai objek. ${ }^{20}$

Seluruh praktik seksualitas perempuan yang diakomodir oleh wacana keagamaan harus berupaya menelusuri akar permasalahan yang

${ }_{18}$ Michel Foucaut, Ingin Tabu: Sejarah Seksualitas (Jakarta: Yayasan Obor Indonesia, 1976), 110-112.

19 Abdul Munir Mulkhan, "Perspektif Sosiologis Kekerasan Fikih terhadap Perempuan," in Islam dan Konstrukesi Seksualitas, ed. Edy Santosa (Yogyakarta: Pustaka Pelajar, 2012), 201.

${ }^{20}$ Elya Munfarida, "Seksualitas Perempuan dalam Islam," Yin Yang Vol. 5, no. 2 (2010). 
terjadi, agar tidak terjadi kesalahan dalam memahami konsep seksualitas dalam Islam. Sebab, paradigma dasar dalam seksualitas Islam seharusnya dijadikan sebagai aturan yang berorientasi pada kehidupan yang lebih berkeadilan. Seksualitas perempuan dalam masyarakat muslim yang bersifat pasif, pada dasarnya bukan bagian dari nalar keagamaan. Konstruksi seksualitas perempuan yang pasif tersebut tidak mendapatkan legitimasi dalam pengalaman Nabi. Sebagai contoh, Siti Khadijah yang melamar Nabi untuk menjadi suaminya, merupakan representasi seksualitas perempuan aktif yang kadang dipandang rendah oleh sebagain kalangan. ${ }^{21}$

Seksualitas menjadi bagian dari sejarah umat manusia yang memiliki keterkaitan dengan agama. Ada dua bentuk hubungan antara seksualitas dengan agama. Pertama, seksualitas sebagai hal yang harus dijauhi, karena berkaitan dengan mitos kejatuhan manusia dari surga. Kedua, seksualitas dipandang sebagai sesuatu yang biasa, bahkan penting dalam kehidupan, karena turut membentuk sejarah manusia. Islam mengambil pandangan yang kedua dan memberikan pengaturan dalam kerangka sosial. ${ }^{22}$

Adapun prinsip fundamental seksualitas dan menjadi kebutuhan dalam kehidupan manusia yakni; pertama, seksualitas adalah sesuatu yang sehat dan alami dalam kehidupan; kedua, seksualitas dalam Islam berkaitan dengan ibadah ritual; ketiga, seksualitas terkait dengan kehidupan keluarga; keempat, hubungan dan kepuasan seksual harus dirasakan secara adil antara suami dan istri. ${ }^{23}$

Sebagai bagian dari eksistensi manusia, dorongan seks tentu dimiliki oleh semua manusia, tanpa membedakan jenis kelamin, status sosial, ras,

${ }^{21}$ Nur Mahmudah, "Konstruksi Seksualitas Perempuan dalam Literatur Pesantren Klasik (Studi Terhadap Kitab Uqud Allujjayn Karya Nawawi Albantani)," Palastren Vol. 3, no. 3 (2010): 290.

22 Ainaul Mardhiyyah, "Konstruksi Seksualitas Perempuan dalam Literatur Pesantren Klasik (Studi Terhadap Kitab Uqud Allujjayn Karya Nawawi Albantani)," Palastren Vol. 6, no. 1 (2013): 71.

23 Ainaul Mardhiyyah, "Konstruksi Seksualitas Perempuan dalam Literatur Pesantren Klasik (Studi Terhadap Kitab Uqud Allujjayn Karya Nawawi Albantani), 72 
etnis, dan lain sebagainya. Oleh karena itu, setiap orang memiliki hak untuk merealisasikan seksualitasnya, sehingga ia bisa mendapatkan kesenangan dan kenikmatan surgawi yang dianugerahkan Tuhan. Kesenangan tersebut bisa diperoleh ketika hak untuk merealisasikan tidak dibatasi oleh normanorma sosial, budaya, atau bahkan agama yang bersifat kontraproduktif. Artinya, norma-norma tersebut tidak memihak satu pihak, dan merugikan pihak lain dalam merealisasikan seksualitasnya. Norma-norma sosial, budaya, dan agama bersifat produktif karena memberikan rambu-rambu yang sesuai dengan etika moralitas. ${ }^{24}$

\section{Tafsir Seksualitas Husein Muhammad}

Karl Mannheim memberi pengertian kepada istilah ideologi dan utopia, sesuai dengan dasar pikirannya dalam upaya memperkenalkan Sosiologi Pengetahuan. Mannheim membedakan fakta empiris yang sudah atau sedang terjadi, dan gejala sosial di masa depan yang belum terjadi. Ideologi dan utopia adalah sama, dalam arti keduanya merupakan gejala sosial yang belum terjadi. Keduanya bukan merupakan fakta empiris. ${ }^{25}$

Namun antara ideologi dan utopia ada sedikit perbedaan. Ideologi merupakan semacam proyeksi ke depan tentang gejala yang akan terjadi di kemudian hari "berdasarkan sistem yang ada". Misalnya, berdasarkan sistem kapitalisme diramalkan akan terjadi pertumbuhan ekonomi yang pesat, karena para pengusaha berusaha meraih laba yang besar, kemudian terjadi proses penetasan kekayaan ke bawah sehingga orang-orang miskin pun akan memperoleh kekayaan.

Model pemikiran tersebut sejalan dengan apa yang dipikirankan oleh Husein Muhammad sebagai tokoh feminis. Husein memberikan gambaran bagaimana seseorang memandang Islam pada masa saat ini, dan untuk masa yang akan datang. Islam pertama-tama dipahami dalam dua perspektif: Islam sejarah dan Islam ideal.

\footnotetext{
${ }^{24}$ Munfarida, "Seksualitas Perempuan dalam Islam."

25 Karl Mannheim, Ideology and Utopia, an Introduction to the Sociology of Knowledge (London: Routledge \& Kegan Paul Ltd, n.d.).
} 


\section{Islam Sejarah}

Islam sejarah, menurut Husein Muhammad adalah Islam yang bergulat, berdialog, dan berproses dalam kebudayaan manusia dan tradisi masyarakat. Dengan kata lain, Islam yang diinterpretasikan dan dipahami oleh manusia sesuai dengan ruang dan waktunya. Dalam konteks ini, tidak dapat dihindari jika Islam dan budaya berkorelasi dalam pola simbiosis mutualistik (saling mempengaruhi). Sehingga Islam sejarah bisa disebut juga dengan Islam kontekstual dan Islam yang tidak pernah berhenti untuk diperjuangkan demi tercapainya Islam Ideal. ${ }^{26}$

Fenomena yang berkembang saat ini, dan terus diperjuangkan untuk menegakan keadilan demi tercapainya Islam ideal, yaitu fenomena penafsiran terhadap agama dalam melanggengkan dan memperkuat budaya patriaki. Kondisi tersebut, menurut Husein Muhammad tercipta karena berakar pada tiga hal, yaitu persoalan androsentrisme, patriarkhi, dan sexism. Androsentrisme memiliki pengertian bahwa tradisi-tradisi agama dikonstruksi, dikembangkan oleh laki-laki dari perspektif laki-laki, oleh karena itu yang menjadi fokus utamanya adalah pengalaman lakilaki. Patriarki menunjukkan adanya dominasi dan superioritas laki-laki dalam wacana dan sejarah agama. Agama atau pemahaman tafsir agama pada akhirnya menjadi sexis. Artinya, pemahaman agama yang dominan memberikan keistimewaan kepada laki-laki dan pengalaman laki-laki serta menempatkan laki-laki sebagai superior, dan pada saat yang sama penempatkan perempuan lebih rendah dan menganggapnya sebagai pihak yang inferior. ${ }^{27}$

Pemahaman tafsir yang dimaksud di atas adalah penafsiran terhadap makna seksualitas antara laki-laki dan perempuan. Dari masa klasik hingga kontemporer, makna seksualitas masih terus diperbincangkan. Husein

${ }^{26}$ Husein Muhammad, Perempuan, Islam, dan Negara: Pergulatan Identitas dan Entitas (Yogyakarta: Qalam Nusantara, 2016), 175.

${ }^{27}$ Inayah Rohmaniyah, "Gender, Androsentrisme dan Sexisme dalam Tafsir Agama," WELFARE: Jurnal Ilmu Kesehatan Sosial Vol. 2, no. 1 (2013): 65-66. 
Muhammad bahkan menyatakan bahwa sepanjang sejarah peradaban manusia, seksualitas perempuan dianggap tidak sama dengan seksualitas laki-laki. Seksualitas perempuan hampir selalu mengalami reduksi secara besar-besaran. Seksualitas perempuan ditempatkan dalam posisi yang direndahkan pada satu sisi, dan dieksploitasi untuk kesenangan laki-laki pada sisi lain. Inilah wajah nyata dari kebudayaan patriaki yang terus dipertahankan sampai hari ini dengan beragam cara, oleh berbagai kepentingan. ${ }^{28}$

Dalam sejarah Islam, seksualitas sering dipengaruhi oleh ideologiideologi yang bias gender, atau ideologi maskulin. Sementara Islam ideal menghendaki relasi kesetaraan, keadilan, dan penghormatan. Satu ayat Alqur'an yang sering dikemukakan untuk menjawab bagaimana Islam memberikan apresiasinya terhadap seksualitas adalah Surat Alrum (30:21). ${ }^{29}$

Makna seksualitas yang terkandung dalam ayat tersebut, menurut Husein Muhammad ada tiga hal: pertama, sebagai cara manusia menyalurkan hasrat libidonya untuk memperoleh kenikmatan/kepuasan seksual. Kedua, merupakan ikhtiar manusia untuk melestarikan kehidupan manusia di muka bumi. Pernikahan dalam arti ini mengandung fungsi prokreasi sekaligus reproduksi. Ketiga, menjadi wahana manusia menemukan tempat ketenangan dan keindahannya. Melalui perkawinan, kegelisahan dan kesusahan hati manusia mendapatkan salurannya. ${ }^{30}$

Selanjutnya, Islam menyatakan bahwa laki-laki dan perempuan dalam relasi seksual adalah sama. Alqur'an menyatakan: "Hunna libasun lakum wa antum libasun lahunna" / mereka (istri) adalah pakaian bagimu dan

${ }^{28}$ Husein Muhammad, Perempuan, Islam, dan Negara: Pergulatan Identitas dan Entitas, 176

29 "Dan di antara tanda-tanda kekuasaan-Nya ialah Dia menciptakan untukmu isteri-isteri dari jenismu sendiri, supaya kamu cenderung dan merasa tenteram kepadanya, dan dijadikan-Nya diantaramu rasa kasih dan sayang. Sesungguhnya pada yang demikian itu benar-benar terdapat tanda-tanda bagi kaum yang berfikir" (Q.S. al-Rum 30: 21).

${ }^{30}$ Husein Muhammad, Perempuan, Islam, dan Negara: Pergulatan Identitas dan Entitas, 
kamu (suami) pakaian bagi mereka (istri)" (Q.S. Albaqarah (2):187). Dalam hal ini Husein Muhammad mengutip pendapat beberapa pakar tafsir untuk menafsirkan ayat di atas. Di antaranya adalah pertama, Ibnu Jarir Althabari yang mengemukakan bahwa metafora untuk arti penyatuan dua tubuh secara interaktif. Kedua, Mujahid dan Qatabah yang menyatakan bahwa masing-masing pasangan saling memberi ketenangan bagi yang lainnya.

Urain di atas menunjukkan bahwa Islam memberikan apresiasi terhadap seksualitas antara laki-laki dan perempuan. Allah melekatkan seks menjadi bagian dari eksistensi manusia, yang dengan hasrat seksual tersebut manusia mampu melanjutkan penciptaan Tuhan. Eksistensi dan kelangsungan hidup manusia dapat terus terpelihara dengan adanya anugerah seks tersebut. Selain itu, eksistensi seks dalam kehidupan manusia juga menjadi spirit dan dorongan untuk terus eksis di tengah berbagai terpaan hidup, karena dorongan seksual mampu mengarahkan seseorang untuk mencari pasangan hidupnya. ${ }^{31}$

Selain sebagai sarana untuk menjaga eksistensi manusia, seks juga bersifat menyenangkan karena dapat memberikan kesenangan yang tidak terbatas, melebihi kesenangan apapun di dunia ini. kesenangan dan kenikmatan yang didapatkan dari seks merupakan manifestasi cinta Allah yang tidak terbatas terhadap manusia, dengan mengizinkan manusia mencicipi kesenangan surgawi. ${ }^{32}$

Oleh sebab itu, kegiatan seksual tidak dapat dilepaskan dari norma sosial, budaya, hukum, maupun agama. Persenggamaan melalui kelamin perempuan pada umumnya diterima sebagai sesuatu yang lazim dilakukan oleh manusia, bahkan dalam beberapa tempat diyakini sebagai satusatunya bentuk tindakan seksual yang dikehendaki. Adapun jenis tindakan seksual yang dilarang, misalnya seks bagi pasangan yang belum menikah, seks yang dilakukan oleh orang-orang yang telah menikah bukan dengan

31 Munfarida, "Seksualitas Perempuan dalam Islam."

32 Suchiko Murata, The Tao of Islam, ed. Rahmani Astuti dan M.S. Nasrullah (Bandung: Mizan, 1997), 250. 
pasangannya, komersialisasi seks, hubungan seks antar sesama jenis, hubungan seks dengan mayat, hubungan seks dengan keluarga dekat, hubungan seks yang dilakukan oleh orang dewasa dengan anak di bawah umur, hubungan seksual yang dilakukan oleh manusia dengan selain manusia, termasuk berhubungan seks saat istri menstruasi. ${ }^{33}$

Sebagai bagian dari eksistensi manusia, dorongan seks tentu dimiliki oleh semua orang, tanpa membedakan jenis kelamin, status sosial, ras, etnis, dan sebagainya. Oleh karena itu, setiap orang memiliki hak untuk merealisasikan seksualitasnya sehingga ia bisa mendapatkan kesenangan dan kenikmatan surgawi yang dianugerahkan Tuhan. Kesenangan ini bisa diperoleh ketika hak untuk merealisasikan dorongan seksualnya tidak direstriksi oleh norma-norma sosial, budaya, atau bahkan agama yang bersifat kontraproduktif. Dalam pengertian ini, norma-norma tersebut tidak memihak satu pihak dan merugikan pihak lain. Norma-norma sosial, budaya, dan agama bersifat produktif karena memberikan rambu-rambu dengan etika moralitas. Sehingga Allah memberikan kebebasan seksual bagi manusia, tetapi dalam batas-batas yang telah ditetapkan. ${ }^{34}$

\section{Islam Ideal}

Kehidupan ideal yang maksud oleh Mannheim dalam buku Ideology and Utopia, memiliki arti sesuatu hal yang tidak terdapat di dunia ini, dan tidak akan pernah bisa direalisasikan dalam kehidupan ini. Mannheim sendiri mengatakan bahwa utopia adalah sistem kemasyarakatan yang sangat ideal. Sehingga mustahil bisa terjadi dalam kehidupan nyata. Walaupun itu mustahil, tetapi setidaknya Islam memberikan beberapa prinsip bagaimana umat mencapai Islam yang rahmatan lil alamin. ${ }^{35}$

Prinsip tersebut menurut Husein Muhammad adalah bagaimana Islam selalu mengidealkan terwujudnya lima prinsip perlindungan

33 Mahmudah, "Konstruksi Seksualitas Perempuan dalam Literatur Pesantren Klasik (Studi Terhadap Kitab Uqud Allujjayn Karya Nawawi Albantani)”, 284.

34 Munfarida, "Seksualitas Perempuan dalam Islam."

35 Karl Mannheim, Ideology and Utopia, an Introduction to the Sociology of Knowledge. 
terhadap hak-hak dasar manusia, yang meliputi: keyakinan, jiwa, akal intelek, kehormatan tubuh dan properti. ${ }^{36}$

Prinsip-prinsip itu merupakan Islam ideal yang diistilahkan oleh Husein Muhammad sebagai sebuah agama untuk manusia, dan dalam kerangka kemanusiaan universal. Islam seperti ini sering diungkapkan dengan istilah Islam rahmatan lil alamin. Oleh karena itulah Islam menjadi faktor penting yang harus dipertimbangkan untuk sebuah perubahan di Indonesia. Perubahan sosial-kebudayaan yang menyangkut paradigma, nilai, norma, dan ajaran-ajaran yang selama ini memandu alur pikiran dan gerak masyarakat. ${ }^{37}$ Jika agama dalam kehidupan berbangsa dan bernegara ditempatkan sebagai basis nilai dan moral, maka agama dan negara bukanlah dua institusi yang dikotomistik. Sepanjang negara menjamin hak-hak dasar (asasi) manusia, lalu dijalankan berdasarkan hukum-hukum yang adil, maka negara tersebut sah dan sejalan dengan misi dan visi agama meski tanpa simbol, atribut, identitas dan aturan spesifik agama. Di sinilah agama dan negara terlihat mempunyai misi yang sama; menegakkan keadilan di antara manusia dan mewujudkan kesejahteraan sosial. ${ }^{38}$

Untuk menegakan keadilan di sini, diperlukan pemahaman mendalam tentang bagaimana Islam berbicara masalah hukum. Pemaknaan dan artikulasi Islam secara modern dan kontekstual menghadirkan dua bentuk dalam pergerakannya, yaitu gerakan moderat dan gerakan ekstrem (radikal). Yang pertama lebih spesifik mengarah kepada bagaimana mengimplementasikan nilai-nilai Islam ke dalam kehidupan berbangsa dan bernegara tanpa terjebak pada simbolisme atau labelisasi Islam (formalisasi Islam). Sementara yang kedua, sama-sama menganggap penting implementasi nilai-nilai Islam dan simbolisme atau formalisasi Islam dalam bentuk negara Islam. Jika yang pertama lebih bersifat

\footnotetext{
36 Muhammad, Perempuan, Islam, dan Negara: Pergulatan Identitas dan Entitas, 175.

37 Nuruzzaman, Kiai Husein Membela Perempuan.

${ }^{38}$ Husein Muhammad, Perempuan, Islam, dan Negara: Pergulatan Identitas dan Entitas, 104.
} 
substantif, mementingkan tujuan terwujudnya cita-cita Islam (keadilan, kedamaian dan kesejahteraan sosial masyarakat) dalam kehidupan seharihari, maka yang kedua lebih mengutamakan berlakunya hukum Islam dalam keseluruhan aspek kehidupan masyarakat. ${ }^{39}$

Dari sini terihat bagaimana hukum Islam itu tidak kaku, dapat berkembang mengakomodir dan mempertimbangkan unsur-unsur sosial baru. Alqur'an dan Sunnah sebagai sumber nilai-nilai independennya yang bersifat permanen, menerima interpretasi manusia yang melibatkan akal dan rasionalisasi, serta dipengaruhi oleh konteks lingkungan. Sehingga hukum berketuhanan juga mengandung sifat rasional dan manusiawi. Maka hukum nasional dapat mencari masukan untuk rintisan perumusan konsep hukum yang berketuhanan dari pemikiran hukum Islam yang dinamis dan terbuka, namun tetap menjaga nilai-nilai independennya. ${ }^{40}$

Tegasnya agama Islam sejak awal kehadirannya, memang dimaksudkan untuk meletakkan dasar-dasar sosial baru yang egaliter, antri diskriminasi, dan anti kekerasan terhadap manusia. ${ }^{41}$ Diskriminasi dalam jenis apapun ditolak keras. Kekerasan, penganiayaan, penghinaan, pelecehan, dan sejenisnya yang dilakukan manusia terhadap manusia lain, apa pun jenis kelamin, agama, etnis, warna kulit, ataupun lainnya merupakan tindakan-tindakan yang tidak dapat dibenarkan oleh agama. Bahkan merupakan pelanggaran terhadap hak asasi manusia. ${ }^{42}$

Agama Islam memberikan jaminan pada kebebasan manusia sebagai elemen paling penting ajaran Ilahi. Dalam Alqur'an, Allah menegaskan bahwa memeluk agama itu bukanlah paksaan. Sebab telah jelas, mana yang baik dan buruk. Demikian pula terkait kebebasan berpendapat, Islam pun meletakkan kedudukannya pada posisi tinggi, bila berangkat dari niat suci

${ }^{39}$ Imam Bonjol Juhari, "Agama sebagai Kesadaran Ideologis: Refleksi Perubahan Sosial Ali Syar'ati," Al-Tabrir Vol. 16, no. 1 (2016): 3-4.

40 Siti Qomariyah, "Transfromasi Hukum Islam dalam Sistem Hukum Nasional: Idealisme dan Realitas," Penelitian Vol. 11, no. 1 (2014): 4. 224

41 Husein Muhammad, Islam Agama Ramah Perempuan Pembelaan Kiai Pesantren,

42 Husein Muhammad, Figh Seksualitas Risalah Islam untuk Pemenuban Hak-Hak Seksualitas, 167.

AL-A'RAF - Vol. XIV, No. 2, Juli - Desember 2017 
semata karena Allah. ${ }^{43}$

Indonesia dikenal sebagai negara dengan penuh keragaman, baik dalam hal agama, tradisi, kesenian, kebudayaan, cara hidup, dan pandangan nilai. Keragaman ini, pada satu sisi bisa menjadi kekuatan yang positif dan konstruktif apabila diarahkan secara benar dan tepat. Sebaliknya, keragaman bisa pula menjadi kekuatan negatif dan destruktif apabila tidak diarahkan secara benar. ${ }^{44}$

\section{Penutup}

Tafsir Alqur'an merupakan hasil karya ulama sebagai petunjuk umat manusia. Namun penafsir juga tidak lepas dari konteks sosiologi dan pengetahuan yang berkembang dalam upaya menafsrikan Alqur'an. Oleh karena itu, penting untuk memperhatikan masyarakat dengan permasalahan yang digelutinya. Jika ada penafsiran yang dirasa tidak sesuai dengan realitas sosial yang ada, seperti tafsir seksualitas, maka menjadi kewajiban intelektual (atau ulama) untuk merekonstuksi tafsir tersebut, agar memberikan solusi terhadap masyarakat sesuai dengan konteks zamannya. Pasalnya, prinsip dasar Islam itu, menurut Husein Muhammad adalah mewujudkan lima prinsip perlindungan terhadap hak-hak dasar manusia, yang meliputi: keyakinan, jiwa, akal intelek, kehormatan tubuh dan properti.

43 Husein Muhammad, Figh Seksualitas Risalab Islam untuk Pemenuban Hak-Hak Seksualitas, 208.

44 Faisal Ismail, Islam, Idealitas Ilabiyah dan Realitas Insaniyah (Yogyakarta: Tiara Wacana Yogya, 1999). 193. 


\section{Referensi}

A, Nenden Lilis. "Faktor-Faktor yang Mempengaruhi Maraknya Karya Sastra yang Mengupas Persialan Seksualitas dan Tubuh dalam Kesusastraan Indonesia Modern Pada Era Reformasi." Yin Yang Vol.4, no. 1 (2009).

Almunawar, Said Agil Husein. Alqur'an Membangun Tradisi Kesaleban Hakiki. Ciputat: Ciputat Press, 2005.

Alrazi, Fakhrudin. Tafsir Almafatih Alghaib. Beirut: Dar Alihya Alturos Alarabi, n.d.

Althabari. Jami' Albayan 'an Ta'wili Alqur'an. Alqahirah: Dar Hijr, 2001.

Alzamakhsyari. Alkasyaf 'an Haqaiq Alghawamid Altanzil. Beirut: Dar Alkitab Alarabi, n.d.

Foucaut, Michel. Ingin Tahu: Sejarah Seksualitas. Jakarta: Yayasan OborIndonesia, 1976.

Ismail, Faisal. Islam, Idealitas, Ilabiyah dan Realitas Insaniyah. Yogyakarta: Tiara Wacana Yogya, 1999.

Juhari, Imam Bonjol. “Agama sebagai Kesadaran Ideologis: Refleksi Perubahan Sosial Ali Syar'ati."' Al-Tahrir Vol. 16, no. 1 (2016): 3-4.

Katsir, Ibn. Tafsir Alqur'an Aladzim. Yaman: Dar Althabi'ah, 1999.

Mahmudah, Nur. "Konstruksi Seksualitas Perempuan dalam Literatur Pesantren Klasik (Studi Terhadap Kitab Uqud Allujjayn Karya Nawawi Albantani)." Palastren Vol. 3, no. 3 (2010): 290.

Mannheim, Karl. Ideology and Utopia, an Introduction to the Sociology of Knowledge. London: Routledge \& Kegan Paul Ltd, n.d.

Mardhiyyah, Ainaul. "Konstruksi Seksualitas Perempuan dalam Literatur Pesantren Klasik (Studi Terhadap Kitab Uqud Al-Lujjayn Karya Nawawi Albantani)." Palastren Vol. 6, no. 1 (2013): 71.

Muhammad, Husein. Islam Agama Ramah Perempuan Pembelaan Kiai Pesantren. Yogyakarta: LKiS, 2001.

. Perempuan, Islam, dan Negara: Pergulatan Identitas dan Entitas. Yogyakarta: Qalam Nusantara, 2016. .dkk. Fiqh Seksualitas Risalah Islam untuk Pemenuban Hak-Hak Seksualitas. Jakarta: Pkbi, 2011. 
Mulkhan, Abdul Munir. "Perspektif Sosiologis Kekerasan Fikih terhadap Perempuan." In Islam dan Konstruksi Seksualitas, edited by Edy Santosa, 201. Yogyakarta: Pustaka Pelajar, 2012.

Munfarida, Elya. "Seksualitas Perempuan dalam Islam.” Yin Yang Vol. 5, no. 2 (2010).

Murata, Suchiko. The Tao of Islam. Edited by Rahmani Astuti dan M.S. Nasrullah. Bandung: Mizan, 1997.

Nuruzzaman. Kiai Husein Membela Perempuan. Yogyakarta: Pustaka Pesantren, 2005.

Qomariyah, Siti. "Transfromasi Hukum Islam dalam Sistem Hukum Nasional: Idealisme dan Realitas.” Penelitian Vol. 11, no. 1 (2014): 4.

Rohmaniyah, Inayah. "Gender, Androsentrisme dan Sexisme dalam Tafsir Agama." WELFARE: Jurnal Ilmu Kesehatan Sosial Vol. 2, no. 1 (2013): 65-66.

Subhan, Zaitunah. Tafsir Kebencian Studi Bias Gender dalam Tafsir Qur'an. Yogyakarta: LKiS, 1999.

Susanti. "Husein Muhammad antara Feminis Islam dan Feminis Liberal." Teosofi Volume 4, no. 1 (2014): 119.

Zakaria, Samsul. "Kepemimpinan Perempuan dalam Persepektif Hukum Islam (Studi Komparatif antara Pemikiran K.H. Husein Muhammad dan Prof. Siti Musdah Mulia)." Khasanah Vol. 6, no. 1 (2013): 78 . 
Muhammad Tobroni

AL-A'RAF - Vol. XIV, No. 2, Juli - Desember 2017 